\title{
Evaluasi Jembatan Petaunan di Ruas Jalan Jajag-Wisata Pulau Merah Kabupaten Banyuwangi
}

\author{
Mirza Ghulam R., M. Shofi’ul Amin dan Erna Suryani \\ Staf Pengajar Jurusan Teknik Sipil, Politeknik Negeri Banyuwangi, Jl. Raya Jember KM.13 \\ Kabat-Banyuwangi, \\ email: mirza@poliwangi.ac.id, shofiul@poliwangi.ac.id,dan erna.sukarno@gmail.com
}

\begin{abstract}
ABSTRAK
Daerah Selatan Kabupaten Banyuwangi mengalami pertumbuhan yang sangat pesat akhir-akhir ini. Perkembangan tersebut dikarenakan daerah Selatan merupakan penghasil komoditi pertanian unggulan, pertambangan emas dan terdapat destinasi wisata unggulan yaitu kawasan wisata pulau merah, Pantai Lampon, Pantai Rajekwesi, Teluk Hijau, Sarongan dan Pantai Sukamade. Perkembangan tersebut mengakibatkan terjadinya peningkatan volume kendaraan penumpang dan kendaraan barang pada ruas jalan Jajag menuju Pulau Merah. Salah satu yang perlu diperhatikan yaitu kendaraan berat yang akan melintas sepanjang jalan Jajag-lokasi tambang. Kondisi tersebut mengakibatkan perlu dilakukannya evaluasi terhadap kondisi jembatan yang ada.

Jembatan Petaunan merupakan salah satu jembatan yang berada pada ruas jalan Jajag menuju kawasan wisata Pulau Merah. Rute ini dilintasi kendaraan barang dan penumpang. Jembatan tersebut berada pada jalur jalan kelas 3B dengan Muatan Sumbu Terberat (MST) 8 ton, lebar kendaraan kurang dari 2,50 m dan panjang kendaraan kurang dari $12 \mathrm{~m}$. Perkembangan daerah Selatan mengakibatkan kendaraan dengan beban MST di atas 8 ton melintasi jembatan Petaunan setiap hari.

Pelaksanaan pemeriksaan dan evaluasi jembatan dilakukan dengan menggunakan metode visual dengan cara mengumpulkan, mengklasifikasikan dan menganalisis data-data yang diperoleh dari lapangan. Metode pemeriksaan dilakukan berdasar Panduan Pemeriksaan Jembatan Bridge Management System (BMS) 1993. Pemeriksaan Khusus jembatan dilakukan dengan menggunakan Non Destructive Test berupa Schmidt Hammer Test.

Dari hasil pemeriksaan didapatkan kerusakan yang terjadi yaitu spalling, retak, bugshole, korosi, tulangan terekspose, honeycomb, retak dan drumminess. Keseragaman mutu elemen struktur termasuk baik dengan nilai konversi kuat tekan $488,76 \mathrm{~kg} / \mathrm{cm}^{2}$ pada gelagar dan pelat lantai jembatan. Nilai koefisien variasi menurut ACI 214R-11 menunjukkan tingkat keseragaman mutu yang sempurna dengan nilai variasi 5,46\%. Kondisi jembatan Petaunan berada pada Nilai Kondisi 3 menurut BMS 1993, Menurut Visual Catalog of Reinforced Concrete Bridge Damage California Department of Transportation (CDOT) kerusakan pada jembatan Petaunan dikategorikan pada Level III.
\end{abstract}

Kata Kunci

Jembatan, Pemeriksaan Visual, hammer test, BMS 1993

\section{Pendahuluan}

Ruas jalan Jajag menuju Pulau Merah merupakan wilayah di Selatan Kabupaten Banyuwangi dengan tingkat perekonomian yang berkembang. Hasil pertanian berupa buah naga, tebu dan jeruk menjadi komoditi unggulan. Selain itu pertambangan emas di Gunung Tumpang Pitu sudah mulai beroperasi dan beberapa kawasan wisata seperti Pulau Merah, Pantai Rajekwesi, Pantai Lampon, Teluk Hijau, Sarongan dan Pantai Sukamade menjadi kawasan wisata unggulan. Perkembangan pusat kegiatan ekonomi tersebut mengakibatkan terjadinya peningkatan volume kendaraan penumpang dan barang pada ruas jalan Jajag menuju Pulau Merah. Salah satu yang perlu diperhatikan yaitu kendaraan berat yang melintas sepanjang jalan Jajag menuju lokasi tambang. Kondisi tersebut mengakibatkan perlu dilakukannya evaluasi terhadap kondisi jembatan yang ada.

Jembatan Petaunan merupakan jembatan dengan gelagar beton yang berada pada kecamatan Bangorejo. Jembatan Petaunan merupakan salah satu jembatan yang berada pada ruas jalan Jajag menuju kawasan wisata Pulau Merah. Rute ini dilintasi kendaraan barang dan penumpang. Jembatan tersebut berada pada jalur dengan kelas jalan 3B dengan Muatan Sumbu Terberat (MST) 8 ton, lebar kendaraan kurang dari 2,50 m dan panjang kendaraan kurang dari $12 \mathrm{~m}$. Perkembangan wilayah Selatan mengakibatkan kendaraan dengan beban MST diatas 8 ton melintasi jembatan Petaunan setiap hari.

Jembatan pada ruas jalan Jajag menuju kawasan wisata Pulau Merah merupakan jembatan yang ratarata dibangun sejak tahun 1985 [1]. Usia jembatan 
yang sudah mencapai 30 tahunan memerlukan pemeriksaan dan pemeliharaan yang intensif.

\section{Studi Pustaka}

Secara umum suatu jembatan berfungsi untuk melayani arus lalu lintas dengan baik. Dalam perencanaan dan perancangan jembatan sebaiknya mempertimbangkan fungsi kebutuhan transportasi, persyaratan teknis dan estetika-arsitektural yang meliputi: aspek lalu lintas, aspek teknis dan aspek estetika [2].

Beberapa tipe kerusakan elemen beton pada jembatan antara lain, korosi baja tulangan, kerontokan beton, beton keropos (honeycombing), beton berongga/berbunyi (drumminess) dan retak [3].

Pemeriksaan jembatan merupakan salah satu bagian yang terpenting dalam sistem informasi manajemen jembatan. Pemeriksaan jembatan mempunyai hubungan utama antara kondisi jembatan dengan rencana pemeliharaan atau peningkatan dalam waktu mendatang. Pemeriksaan jembatan bertujuan untuk meyakinkan bahwa jembatan masih aman berfungsi atau perlu dilakukan tindakan tertentu untuk pemeliharaan dan perbaikan secara berkala [4].

Tingkat kerusakan perlu diidentifikasi sebelum dilakukan langkah selanjutnya. Sistem penilaian untuk elemen yang rusak terdiri atas serangkaian pertanyaan yang berjumlah lima mengenai kerusakan yang ada [4]. Pertanyaan tersebut disajikan pada Tabel 1 dan hasil penilaian kondisi kerusakan elemen jembatan disajikan pada Tabel 2.

Tabel 1 Kriteria penentuan Nilai Kondisi (BMS, 1993)

\begin{tabular}{ccc}
\hline Nilai & Kriteria & Nilai \\
\hline Struktur & Berbahaya & 1 \\
$(\mathrm{~S})$ & Tidak Berbahaya & 0 \\
\hline Kerusakan & Parah & 1 \\
$(\mathrm{R})$ & Tidak Parah & 0 \\
\hline Kuantitas & Lebih dari 50 \% & 1 \\
$(\mathrm{~K})$ & Kurang dari 50 \% & 0 \\
\hline Fungsi & Elemen tidak berfungsi & 1 \\
$(\mathrm{~F})$ & Elemen berfungsi & 0 \\
\hline Pengaruh & Mempengaruhi elemen & 1 \\
$(\mathrm{P})$ & lain & 0 \\
\multicolumn{3}{c}{ Tidak mempengaruhi } \\
\hline NILAI & elemen lain \\
KONDISI & NK $=\mathrm{S}+\mathrm{R}+\mathrm{K}+\mathrm{F}+$ & $0-5$ \\
$(\mathrm{NK})$ & $\mathrm{P}$ \\
\hline \multicolumn{2}{c}{} \\
\hline
\end{tabular}

Tabel 2 Penilaian Kondisi Kerusakan Elemen Jembatan (BMS, 1993)

\begin{tabular}{cl}
\hline Nilai Kondisi & \multicolumn{1}{c}{ Uraian } \\
\hline 0 & Jembatan dalam keadaan baru, tanpa kerusakan yang cukup jelas. \\
\hline I & $\begin{array}{l}\text { Elemen tidak mengalami kerusakan atau penurunan mutu. Mungkin terjadi sedikit } \\
\text { perubahan warna, bintik-bintik, dan/atau retak yang halus sekali. }\end{array}$ \\
\hline II & $\begin{array}{l}\text { Retak kecil dan sedikit terjadi penggompalan tetapi menyebabkan terjadinya. Korosi } \\
\text { pada baja tulangan atau penurunan mutu pada sistem prategang }\end{array}$ \\
\hline III & $\begin{array}{l}\text { Terjadi sedikit bagian beton yang lepas, adanya retak yan mulai terlihat. Tidak ada } \\
\text { penurunan mutu pada sistem prategang. Mungkin terjadi sedikit korosi pada baja } \\
\text { tulangan tetapi pada bagian yang non struktural. Tidak memerlukan analisa secara } \\
\text { khusus akibat kerusakan atau penurunan kelayanan elemen pada jembatan. }\end{array}$ \\
\hline IV & $\begin{array}{l}\text { Sudah terjadi pemisah pada beton dan gompal atau retak atau korosi pada baja } \\
\text { tulangan. Terlihat adanya penurunan mutu pada sistem prategang (seperti hilangnya } \\
\text { daya lekat, putusnya strand atau wire, korosi atau hancurnya bagian angkur dsb). } \\
\text { Diperlukan analisa akibat kerusakan tersebut terhadap kekuatan dan/atau layan } \\
\text { elemen jembatan. }\end{array}$ \\
\hline Seluruh elemen jembatan runtuh atau tidak berfungsi lagi. \\
\hline
\end{tabular}

Kerusakan level I menunjukkan tidak ada kerusakan, sedangkan kerusakan pada level $\mathrm{V}$ menunjukkan kegagalan lokal atau komponen runtuh [5]. Penilaian kondisi jembatan disajikan pada Tabel 3.

Monitoring secara non destructive sebaiknya digunakan dalam mengevaluasi jembatan [6]. Hal ini dimaksudkan untuk mengetahui kinerja jembatan serta teknik perbaikan komponennya yang berbeda dengan dilengkapi program inspeksi visual yang dijadwalkan secara rutin.
Salah satu mekanisme dan instrumen pemeriksaan Non Destructive Test (NDT) adalah dengan menggunakan Schmidt Rebound Hammer Test. Schmidt Rebound Hammer Test digunakan pada prosedur Pemeriksaan Khusus dengan tujuan untuk mengestimasi keseragaman mutu material pada elemen struktur beton. Untuk mengidentifikasi variabilitas, digunakan standar kontrol [7]. 
Tabel 3 Penilaian kondisi kerusakan jembatan (California Department of Transportation/CDOT, 2006)

\begin{tabular}{ccccc}
\hline Level & $\begin{array}{c}\text { Klasifikasi } \\
\text { Kerusakan }\end{array}$ & $\begin{array}{c}\text { Keterangan } \\
\text { Kerusakan }\end{array}$ & $\begin{array}{c}\text { Keterangan } \\
\text { Perbaikan }\end{array}$ & $\begin{array}{c}\text { Keterangan } \\
\text { Sosial-Ekonomi }\end{array}$ \\
\hline I & Tidak ada & $\begin{array}{c}\text { Retak yang } \\
\text { nyaris tak terlihat }\end{array}$ & $\begin{array}{c}\text { Tanpa } \\
\text { Perbaikan }\end{array}$ & $\begin{array}{c}\text { Operasional } \\
\text { sepenuhnya }\end{array}$ \\
\hline II & Kecil & Retak & $\begin{array}{c}\text { Kemungkinan } \\
\text { diperbaiki }\end{array}$ & Operasional \\
\hline III & Sedang & $\begin{array}{c}\text { Retak Terbuka, } \\
\text { Timbulnya Pecahan }\end{array}$ & $\begin{array}{c}\text { Perbaikan } \\
\text { yang minim }\end{array}$ & $\begin{array}{c}\text { Keselamatan } \\
\text { hidup }\end{array}$ \\
\hline IV & Besar & $\begin{array}{c}\text { Retak yang luas, } \\
\text { Pecahan Panjang }\end{array}$ & Diperbaiki & $\begin{array}{c}\text { Mendekati } \\
\text { keruntuhan }\end{array}$ \\
\hline V & Runtuh & $\begin{array}{c}\text { Perubahan yang } \\
\text { Terlihat jelas }\end{array}$ & Diganti & Runtuh \\
\hline
\end{tabular}

Kondisi struktural jembatan beton box girder dipantau dua kali dengan mendeteksi dan melokalisir potensi kerusakan pada bangunan atas jembatan [8]. Parameter dari struktur dasar diidentifikasi dan ditentukan di lapangan dan digunakan sebagai masukan untuk metode Non Destructive Test.

Pemantauan jembatan dan pemeliharaan merupakan tugas mahal, namun penting dalam menjaga infrastruktur transportasi nasional yang aman [9].

Metode mengevaluasi kerusakan lendutan jembatan melalui uji defleksi, disajikan dalam penelitian [10]. Pekerjaan dilakukan pada jembatan baja tua tipe deck yang rusak menggunakan Total Station dan Dial Gauge dengan pembebanan titik tengah.

\section{Metodologi}

Penelitian dilakukan dengan serangkaian pemeriksaan secara visual, detail dan khusus pada jembatan Petaunan. Hasil survey lapangan selanjutnya diuji di Laboratorium Struktur Program Studi Teknik Sipil Politeknik Negeri Banyuwangi. Metode penelitian ditunjukkan pada Gambar 1.

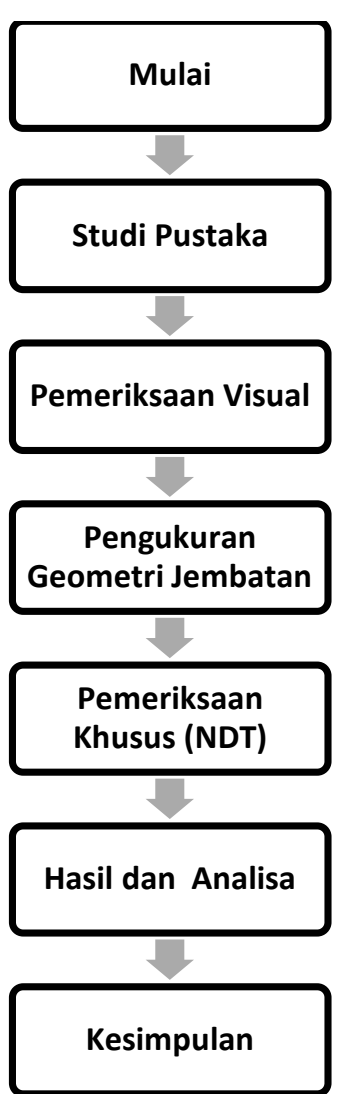

Gambar 1. Bagan Alir Metodologi Penelitian

Secara umum, penelitian ini dilakukan dengan metode penelitian berbasis pemeriksaan lapangan. Fokus pemeriksaan adalah jembatan Petaunan yang terdapat pada ruas jalan Jajag-Bangorejo (KM 13+380) yang merupakan ruas utama menuju kawasan wisata Pulau Merah.

\section{III.1 Pengukuran Geometri Jembatan}

Pengukuran geometri dilakukan untuk mendapatkan data geometri jembatan secara eksisting. Data geometri perencanaan dan as built drawing tidak didapatkan dari Dinas Pekerjaan Umum Bina Marga Propinsi dan Dinas Pekerjaan Umum Bina Marga Kabupaten, sehingga data-data eksisting jembatan tidak didapatkan. 


\section{III.2 Pemeriksaan Visual}

Berdasarkan Panduan Pemeriksaan pada Bridge Management System (BMS) 1993 dan Pedoman Perbaikan dan Perkuatan Struktur Beton pada Jembatan (022/BM/2011), dilakukan pemeriksaan detail secara visual. Pemeriksaan detail secara visual bertujuan untuk mengetahui kondisi jembatan dan elemennya guna mempersiapkan strategi penanganannya [3]. Pemeriksaan visual dilakukan untuk mengamati dan mencatat kondisi komponenkomponen jembatan secara visual serta untuk mengetahui cacat-cacat yang terdapat pada komponen struktur eksisting.

\section{III.3 Pemeriksaan Khusus menggunakan Schmidt Rebound Hammer Test}

Pemeriksaan khusus dilakukan karena kurangnya data setelah dilakukan pemeriksaan detail [3].
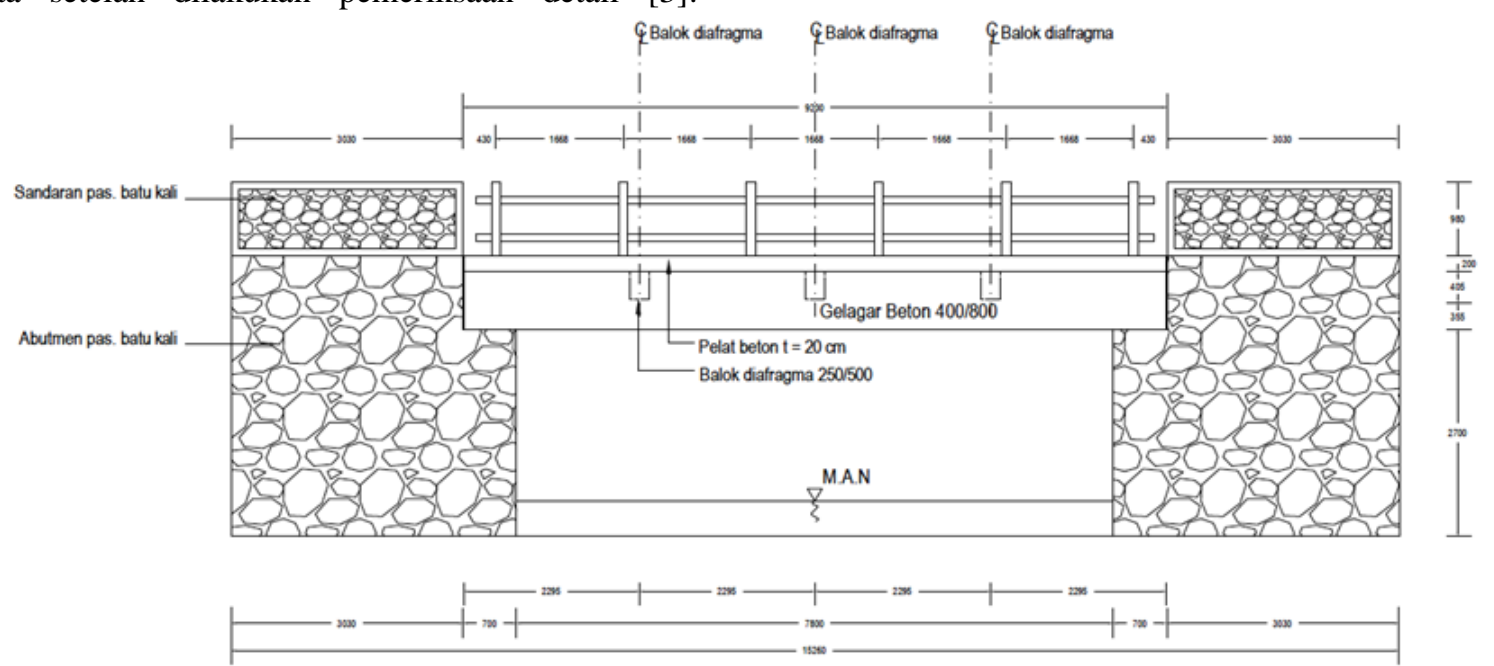

Gambar 2. Tampak memanjang jembatan Petaunan

\section{IV.2 Data Umum Jembatan Petaunan}

Data umum jembatan disajikan sebagai berikut:
a. Nomor
: $\quad 3510.2 .218 .002$ Jembatan
b. Lokasi KM dari Genteng
c. Ruas Jalan$$
: \quad 13+380
$$
d. Bentang
e. Panjang
f. Lebar
: Jajag-Bangorejo Banyuwangi
g. Bangunan Atas
h. Lantai
i. Bangunan Bawah

Situasi jembatan ditunjukkan pada Gambar 3.
Pemeriksaan secara khusus melibatkan peralatan pemeriksaan material, kekuatan material dan elemen struktur jembatan. Salah satu instrumen pemeriksaan khusus yang digunakan adalah Schmidt Rebound Hammer Test. Hal ini dilakukan untuk mengetahui keseragaman mutu material yang tidak merusak jembatan (Non Destructive Test/NDT).

\section{Analisis dan Pembahasan}

\section{IV.1 Konfigurasi Jembatan}

Jembatan Petaunan merupakan jembatan beton dengan panjang jembatan 9,20 $\mathrm{m}$ dan bentang jembatan 7,80 m. Konfigurasi jembatan ditunjukkan pada Gambar 2. 


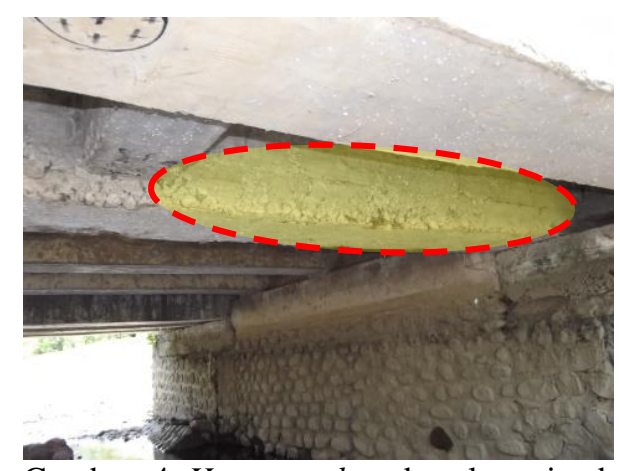

Gambar 4. Honeycomb pada gelagar jembatan

Gambar 5 menunjukkan kerusakan pada gelagar jembatan berupa bugshole. Kerusakan ini berupa lubang sebesar sarang serangga. Hal ini menunjukkan bahwa kondisi beton kurang padat dan terdapat ruang di belakang selimut beton.

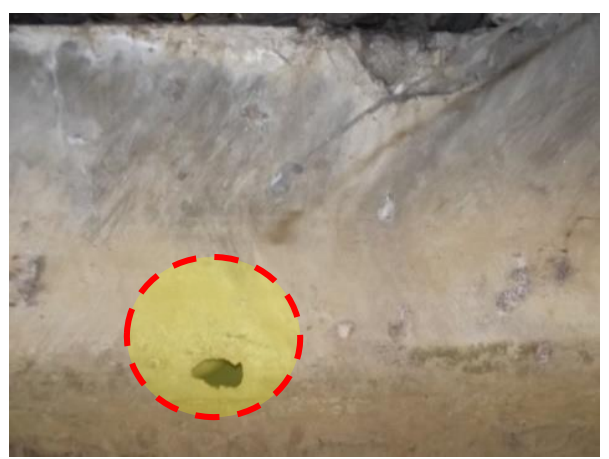

Gambar 5. Bugshole pada gelagar jembatan

Gambar 6 menunjukkan kerusakan pada gelagar jembatan dengan tipe kerusakan berupa retak dan drumminess. Kerusakan yang terdapat pada gelagar jembatan dimungkinkan akibat adanya dorongan dari baja tulangan. Gelagar beton mengalami retak yang memanjang dan menimbulkan bunyi pada saat dipukul.

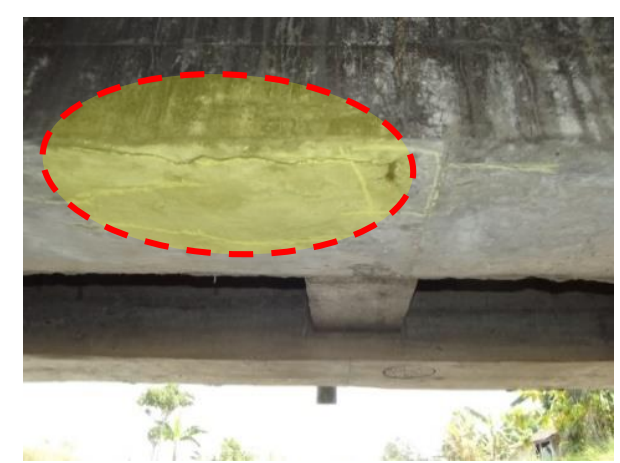

Gambar 6. Retak pada gelagar jembatan

Gambar 7 menunjukkan kerusakan gelagar dengan tipe honeycomb. Kerusakan tersebut dimungkinkan terjadi karena segregasi selama pelaksanaan.

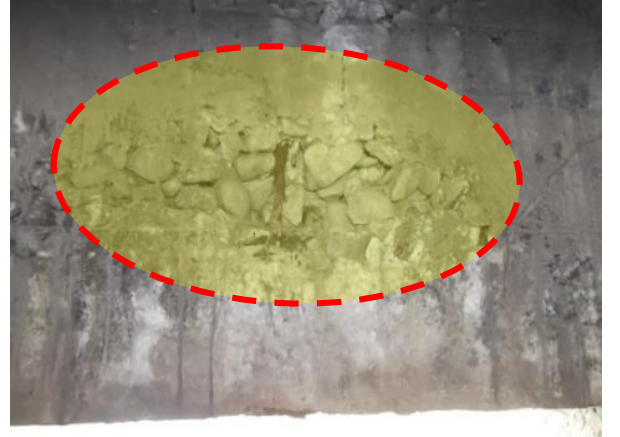

Gambar 7. Honeycomb pada gelagar jembatan

Gambar 8 menunjukkan kerusakan pada gelagar jembatan dengan tipe-spalling, tulangan berkarat dan tulangan tersekspose. Kerusakan yang terdapat pada gelagar jembatan dimungkinkan akibat adanya produk korosi yang mengembang dan mendorong selimut beton. Selanjutnya, muncul retak dan spalling akibat pengembangan tulangan.

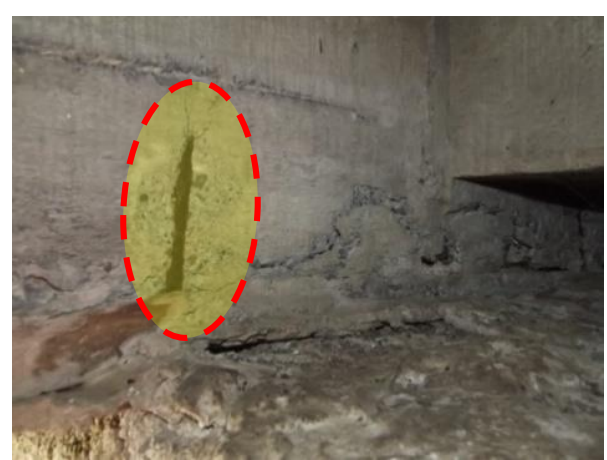

Gambar 8. Korosi, spalling dan tulangan terekspose pada gelagar jembatan

Gambar 9 menunjukkan kerusakan gelagar dengan tipe honeycomb. Kerusakan tersebut dimungkinkan karena terjadinya segregasi selama pelaksanaan.

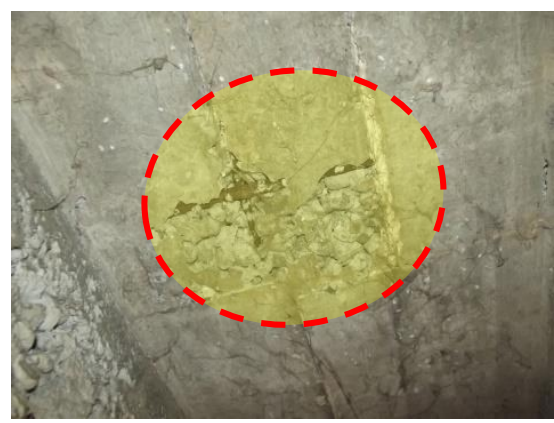

Gambar 9. Honeycomb pada pelat jembatan

\section{IV.4 Pemeriksaan Schmidt Rebound Hammer Test}

Hasil pengujian Schmidt Rebound Hammer Test pada balok dan pelat jembatan Petaunan ditunjukkan pada Tabel 4. Korelasi kuat tekan beton dan sebaran nilai keseragaman mutu pelat dan balok jembatan Petaunan ditunjukkan pada Gambar 10. Rentang nilai angka pantul pada pilar jembatan sisi Banyuwangi cukup tinggi, yaitu $\mathrm{R}_{\text {rata-rata }}$ tertinggi 57,28 dan $\mathrm{R}_{\text {rata-rata }}$ terendah 38,83 . 
Ringkasan hasil analisis mutu beton pada pilar jembatan :

- Kuat tekan rata-rata, $\sigma_{\mathrm{bm}}=488,76 \mathrm{~kg} / \mathrm{cm}^{2}$.

- Koefisien variasi, $\mathrm{V}=5,46 \%$.

- Kuat tekan batas bawah, $\sigma \mathrm{bk}=295,8 \mathrm{~kg} / \mathrm{cm}^{2}$.

Tabel 4 Hasil pengukuran angka pantul permukaan beton

\begin{tabular}{c|c|c}
\hline $\begin{array}{c}\text { No. } \\
\text { Sampel }\end{array}$ & $\mathbf{R}_{\text {RATA }}$ & $\begin{array}{c}\mathbf{\sigma}_{\mathbf{b}} \\
\left(\mathbf{k g} / \mathbf{c m}^{2}\right)\end{array}$ \\
\hline 1 & 57.28 & 637.5 \\
\hline 2 & 53.34 & 600.8 \\
\hline 3 & 39.88 & 316.2 \\
\hline 4 & 57.06 & 637.5 \\
\hline 5 & 42.19 & 367.2 \\
\hline 6 & 38.83 & 295.8 \\
\hline 7 & 49.57 & 514.1 \\
\hline 8 & 40.41 & 336.6 \\
\hline 9 & 52.33 & 575.3 \\
\hline 10 & 47.71 & 469.2 \\
\hline 11 & 52.05 & 575.3 \\
\hline 12 & 50.53 & 539.6 \\
\hline
\end{tabular}

Nilai korelasi angka pantul dengan kuat tekan beton menunjukkan nilai rata-rata $488,76 \mathrm{~kg} / \mathrm{cm}^{2}$. Nilai rata-rata tersebut tidak bisa digunakan untuk memastikan nilai kuat tekan beton aktual, melainkan sebagai indikator kekerasan permukaan beton pada elemen struktur jembatan Petaunan.

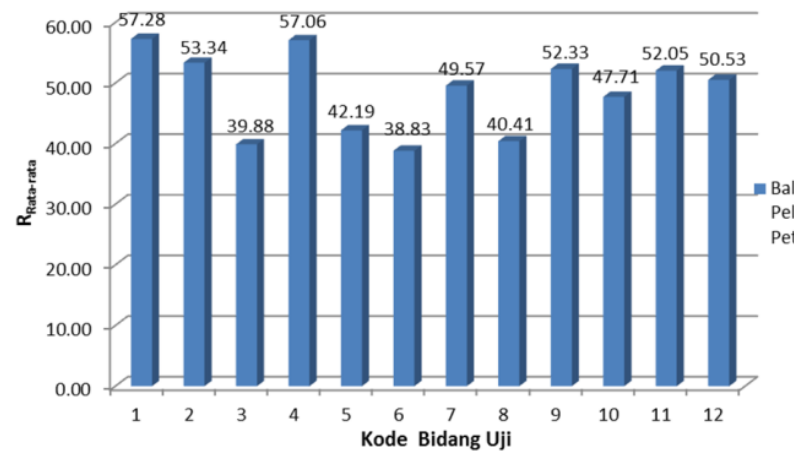

Gambar 10. Uji Schmidt Rebound Hammer Test pada elemen pelat dan balok Jembatan Petaunan

Nilai koefisien variasi di bawah $7 \%$ untuk mutu beton $\geq 35 \mathrm{MPa}$ diindikasikan mempunyai tingkat keseragaman mutu yang sempurna [6].

Dengan demikian dapat disimpulkan bahwa komponen struktur pelat dan balok jembatan Petaunan memiliki tingkat keseragaman mutu yang sempurna.

\section{IV.5 Penilaian Kondisi Jembatan}

Diperoleh jembatan berada pada Nilai Kondisi 3 yaitu kerusakan yang membutuhkan perhatian khusus (kerusakan akan menjadi serius dalam 12 bulan ke depan) [3]. Penilaian Kondisi jembatan Petaunan berdasarkan BMS 1993 ditunjukkan pada Tabel 5.

Kerusakan pada jembatan Petaunan dikategorikan pada Level III yang berarti memiliki kerusakan sedang [4]. Kerusakan yang terjadi berupa retak terbuka dan timbulnya pecahan (gompal, spalling dan sebagainya). Efek sosial ekonomi yang timbul akibat kerusakanberupa terganggunya kelangsungan operasional jembatan.Penanganan yang bisa dilakukan adalah dengan perbaikan minimum. Penentuan kerusakan menurut Visual Catalog of Reinforced Concrete Bridge Damage California Department of Transportation (CDOT) .

Tabel 5 Contoh penentuan Nilai Kondisi (NK) pada elemen Diafragma Jembatan Petaunan

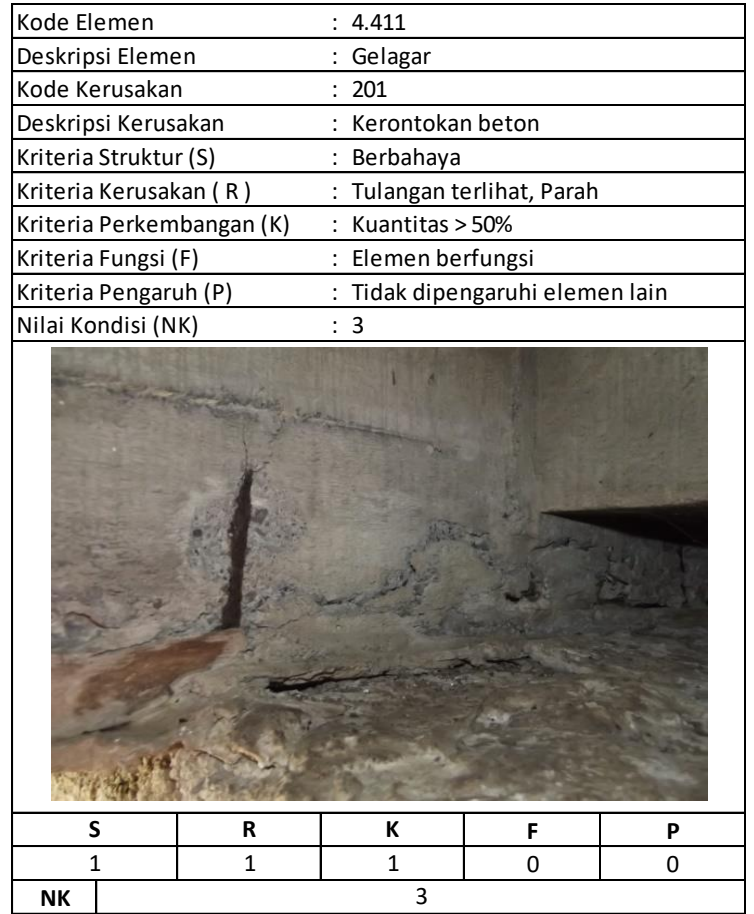

\section{Kesimpulan}

Beberapa hal penting yang bisa disimpulkan dalam studi ini adalah:

- Jembatan Petaunan merupakan jembatan beton bertulang dengan gelagar beton cor insitu.

- Kerusakan yang terjadi pada jembatan Petaunan antara lain, spalling, retak, bugshole, korosi, tulangan terekspose, honeycomb, retak dan drumminess.

- Keseragaman mutu material elemen struktur termasuk baik dengan nilai konversi kuat tekan $488,76 \mathrm{~kg} / \mathrm{cm}^{2}$ pada gelagar dan pelat lantai jembatan. 
- Nilai koefisien variasi menurut ACI 214R-11 menunjukkan tingkat keseragaman mutu yang sempurna dengan nilai variasi 5,46\%.

- Nilai Kondisi jembatan Petaunan berada pada Nilai Kondisi 3 menurut BMS 1993, Menurut Visual Catalog of Reinforced Concrete Bridge Damage California Department of Transportation (CDOT) kerusakan pada jembatan Petaunan dikategorikan pada Level III.

- Nilai Kondisi jembatan yang ditetapkan oleh Bridge Management System (BMS) 1993 dan California Department of Transportation (CDOT) menunjukkan tingkat kerusakan yang sama.

- Pada Nilai Kondisi 3 dengan rekomendasi perbaikan dalam waktu 12 bulan kedepan, jembatan Petaunan masih mampu melayani beban jalan.

- Pada jembatan Petaunan yang terletak pada kelas jalan IIIB dengan beban jalan diatas batas kelas jalan, jembatan Petaunan belum menunjukkan kerusakan yang diakibatkan oleh beban berlebih. Kerusakan yang muncul, mayoritas dikarenakan kerusakan bahan.

- Tebal selimut yang tipis mengakibatkan tulangan mudah terserang korosi. Produk korosi akan mengembang dan mendorong selimut beton sehingga beton mengalami retak dan selanjutnya terjadi spalling.

- Rongga yang terjadi akibat segregasi pada saat pelaksanaan, mengakibatkan munculnya honeycombing pada hasil akhir beton. Ronggarongga tersebut menjadi pintu masuk bagi zat kimia dan mengakibatkan kerusakan bahan pada beton.

\section{Daftar Pustaka}

[1] Bina Marga, Banyuwangi, (2015): Laporan UPT

[2] Supriyadi, B., dan Muntohar, A.S., (2007): Jembatan, CV. BETA Offset, Yogyakarta.

[3] Direktorat Jenderal Bina Marga (022/BM/2011), (2011), Perbaikan dan Perkuatan Struktur Beton pada Jembatan, Bina Marga, Jakarta.

[4] Bridge Management System (BMS), (1993): Panduan Pemeriksaan Jembatan, Direktorat Jenderal Bina Marga Departemen Pekerjaan Umum Republik Indonesia, Jakarta.

[5] California Departement of Transportation, (2006), Visual Catalog of Reinforced Concrete Bridge Damage, California.

[6] T. DeWolf J., G. Lauzon R., dan P. Culmo M., (2002): Monitoring Bridge Performance, Journal Structural Health Monitoring, Vol. 1 (2): 129-138.
[7] American Concrete Institute (ACI 214R-11), (2011): Guide to Evaluation of Strength Test Result of Concrete, Farmington Hills.

[8] Park, S., Stubbs N., Bolton R., Choi S., dan Sikorsky C., (2001): Field Verification of the Damage Index Method in a Concrete BoxGirder Bridge via Visual Inspection, Journal Computer Aided Civil and Infrastructure Engineering, Vol. 16 (1):58-70.

[9] Abdel Qader I., Abudayyeh O., dan E. Kelly M., (2003): Analysis of Edge Detection Techniques for Crack Identification in

[10] Kumar Walia S., Kumar Vinayak H. dan Parti R.,(2014): Damage Evaluation and Partial Retrofitting of Old Steel Bridge, International Journal of Scientific and Engineering Research, Vol. 5(5):471-481. 